In cooperation with Texas A\&M University AgriLife

\title{
Direct-Current Resistivity Profiling at the Pecos River Ecosystem Project Study Site near Mentone, Texas, 2006
}

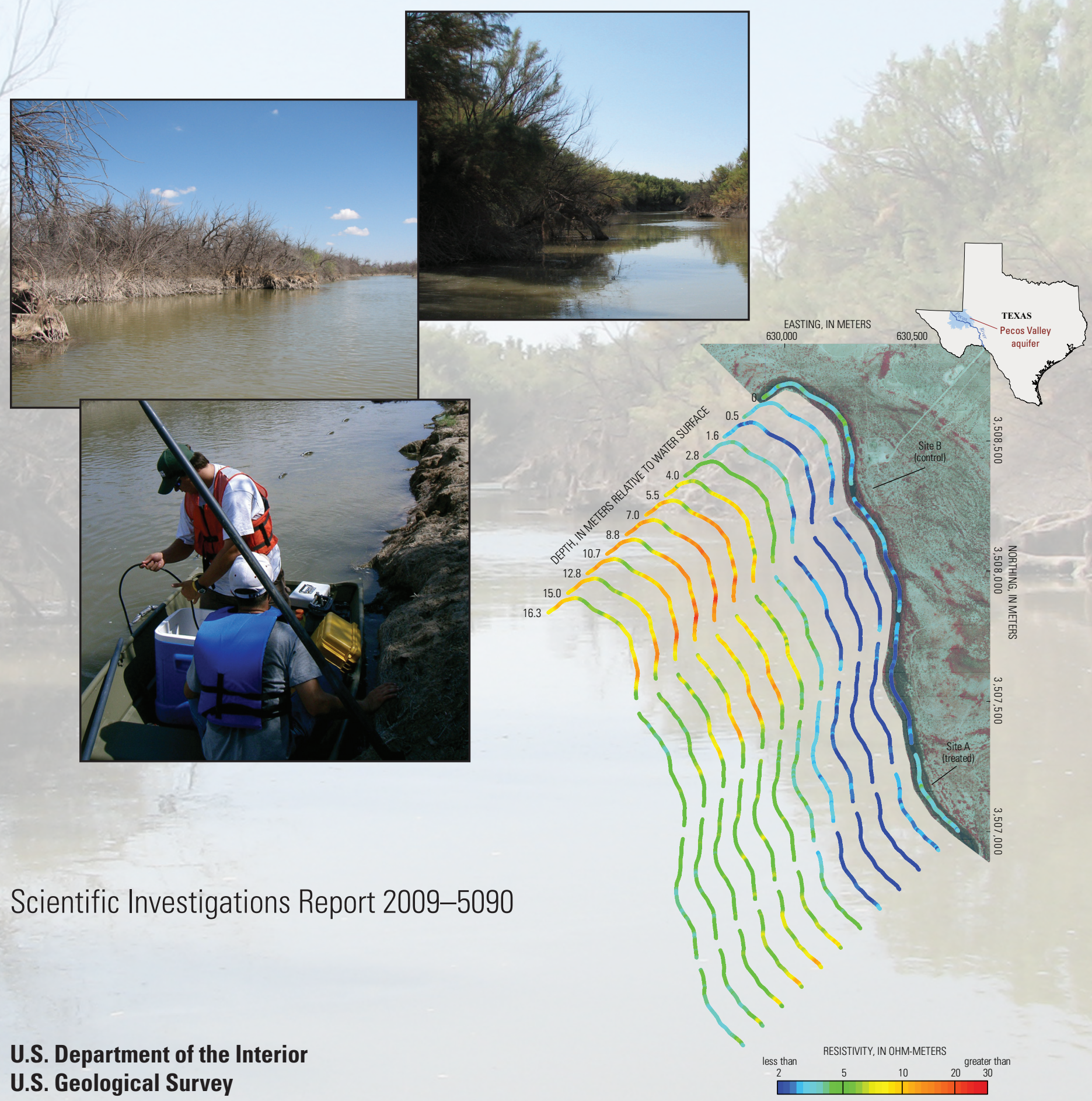


(C)

(B)

(A)

(D)

\section{Front cover:}

(A) Waterborne direct-current continuous resistivity profiling along Pecos River near Mentone, Texas.

(B) Treated reach (site A) along Pecos River near Mentone, Texas, 2006.

(C) Untreated reach (site B) along Pecos River near Mentone, Texas, 2006.

(D) Inverse modeling results for waterborne continuous direct-current resistivity profile along Pecos River near Mentone, Texas. 


\section{Direct-Current Resistivity Profiling at the Pecos River Ecosystem Project Study Site near Mentone, Texas, 2006}

By Andrew P. Teeple, Alyson K. McDonald, Jason D. Payne, and Wade H. Kress

In cooperation with Texas A\&M University AgriLife

Scientific Investigations Report 2009-5090 


\section{U.S. Department of the Interior \\ KEN SALAZAR, Secretary}

\section{U.S. Geological Survey Suzette M. Kimball, Acting Director}

U.S. Geological Survey, Reston, Virginia: 2009 This and other USGS information products are available at http://store.usgs.gov/
U.S. Geological Survey
Box 25286 , Denver Federal Center
Denver, CO 80225
To learn about the USGS and its information products visit http://www.usgs.gov/
1-888-ASK-USGS

Any use of trade, product, or firm names is for descriptive purposes only and does not imply endorsement by the U.S. Government.

Although this report is in the public domain, permission must be secured from the individual copyright owners to reproduce any copyrighted materials contained within this report.

Suggested citation:

Teeple, A.P., McDonald, A.K., Payne, J.D., and Kress, W.H., 2009, Direct-current resistivity profiling at the Pecos River Ecosystem Project study site near Mentone, Texas, 2006: U.S. Geological Survey Scientific Investigations Report 2009-5090, $11 \mathrm{p}$. 


\section{Contents}

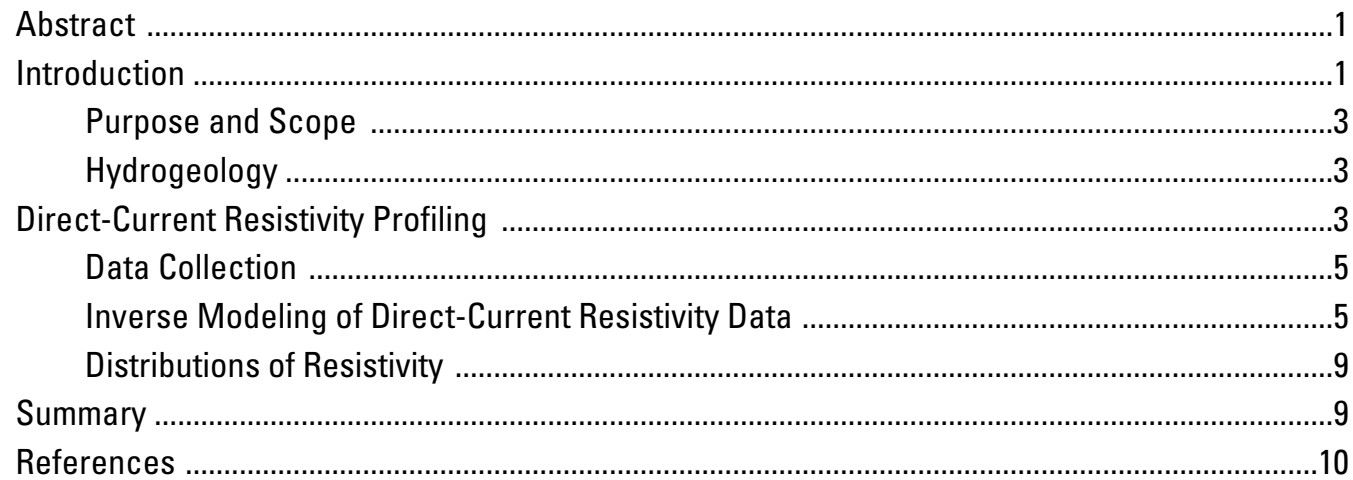

\section{Figures}

1. Map showing location of Pecos River Ecosystem Project study site near Mentone, Texas

2. Photographs showing treated reach (site $A$ ) and untreated (control) reach (site $B$ ) along the Pecos River, Pecos River Ecosystem Project study site near Mentone, Texas, 2006

3. Diagram showing layout of waterborne direct-current continuous resistivity profiling system

4. Photographs showing (A) IRIS Instruments Syscal Pro direct-current resistivity system and (B) stainless steel electrode connected to a direct-current resistivity cable near the Pecos River, Pecos River Ecosystem Project study site near Mentone, Texas, 2006

5. Map showing land-based direct-current resistivity profile at site $B$ (control) and waterborne continuous direct-current resistivity profile along the river adjacent to site A (treated) and site B (control), Pecos River Ecosystem Project study site near Mentone, Texas

6. Diagrams showing $(A)$ reciprocal-Schlumberger and (B) dipole-dipole arrays used at the Pecos River Ecosystem Project study site near Mentone, Texas, 2006

7. Photographs showing waterborne direct-current resistivity equipment used the Pecos River Ecosystem Project study site near Mentone, Texas, 2006: (A) punt boat with equipment and trolling motor, (B) waterborne electrode streamer with foam insulation for flotation, and (C) IRIS Instruments Syscal Pro resistivity meter

8. Smooth inverse model results of direct-current resistivity, Pecos River Ecosystem Project study site near Mentone, Texas, 2006: (A) resistivity section from reciprocal-Schlumberger land-based profile at the control site, (B) resistivity section from reciprocal-Schlumberger waterborne continuous profile from subreach of the river adjacent to the land-based profile, and $(C)$ resistivity section from dipole-dipole waterborne continuous profile from subreach of the river adjacent to the land-based profile

9. Smooth inverse model results of waterborne continuous direct-current resistivity profiles along 2.279-kilometer reach of the river adjacent to treated and control sites, Pecos River Ecosystem Project study site near Mentone, Texas, 2006:

(A) resistivity section from reciprocal-Schlumberger profile, and (B) resistivity section from dipole-dipole profile 


\section{Conversion Factors and Datums}

\section{Inch/Pound to SI}

\begin{tabular}{lll}
\hline \multicolumn{1}{c}{ Multiply } & By & \multicolumn{1}{c}{ To obtain } \\
\hline & Length & \\
\hline kilometer $(\mathrm{km})$ & 0.6214 & mile (mi) \\
meter $(\mathrm{m})$ & 3.281 & foot (ft) \\
millimeter $(\mathrm{mm})$ & 0.03937 & inch (in) \\
\hline & Resistivity & \\
\hline ohm-meter (ohm-m) & 3.281 & ohm-foot (ohm-ft) \\
\hline
\end{tabular}

\section{Datums}

Vertical coordinate information is referenced to the North American Vertical Datum of 1988 (NAVD 88).

Horizontal coordinate information is referenced to the North American Datum of 1983 (NAD 83).

Altitude, as used in this report, refers to distance above the vertical datum. 


\title{
Direct-Current Resistivity Profiling at the Pecos River Ecosystem Project Study Site near Mentone, Texas, 2006
}

\author{
By Andrew P. Teeple', Alyson K. McDonald², Jason D. Payne', and Wade H. Kress ${ }^{1}$
}

\section{Abstract}

The U.S. Geological Survey, in cooperation with Texas A\&M University AgriLife, did a surface geophysical investigation at the Pecos River Ecosystem Project study site near Mentone in West Texas intended to determine shallow (to about 14 meters below the water [river] surface) subsurface composition (lithology) in and near treated (eradicated of all saltcedar) and control (untreated) riparian zone sites during June-August 2006. Land-based direct-current resistivity profiling was applied in a 240-meter section of the riverbank at the control site, and waterborne direct-current continuous resistivity profiling (CRP) was applied along a 2.279-kilometer reach of the river adjacent to both sites to collect shallow subsurface resistivity data. Inverse modeling was used to obtain a nonunique estimate of the true subsurface resistivity from apparent resistivity calculated from the field measurements. The land-based survey showed that the subsurface at the control site generally is of relatively low resistivity down to about 4 meters below the water surface. Most of the section from about 4 to 10 meters below the water surface is of relatively high resistivity. The waterborne CRP surveys convey essentially the same electrical representation of the lithology at the control site to 10 meters below the water surface; but the CRP surveys show considerably lower resistivity than the land-based survey in the subsection from about 4 to 10 meters below the water surface. The CRP surveys along the 2.279-kilometer reach of the river adjacent to both the treated and control sites show the same relatively low resistivity zone from the riverbed to about 4 meters below the water surface evident at the control site. A slightly higher resistivity zone is observed from about 4 to 14 meters below the water surface along the upstream approximately one-half of the profile than along the downstream one-half. The variations in resistivity could not be matched to variations in lithology because sufficient rock samples were not available.

\section{Introduction}

Saltcedar, or tamarisk (Tamarix spp.), is an invasive phreatophyte species that develops dense thickets in riparian systems (DeLoach, 1997; Weeks and others, 1987). Among its many known and suspected effects on stream corridors, water consumption in stream corridors dominated by saltcedar could be greater on a per-acre basis than consumption in corridors dominated by native phreatophytes (Kolb, 2001). Dense saltcedar stands on stream banks also accumulate sediment in their thick root systems, which gradually narrows stream channels and increases flooding (Tamarisk Coalition, 2009).

The Pecos River Ecosystem Project (PREP) is a largescale ecosystem restoration program designed to eliminate saltcedar and replace it with reintroduced native plants and grasses. Preliminary assessments of water quality indicate that saltcedar control will decrease salinity and increase flow in the Pecos River (Hart and others, 2005; Texas State Soil and Water Conservation Board and Texas Commission on Environmental Quality, 2006). As part of the PREP, Texas A\&M University AgriLife initiated a saltcedar-control program in 1999; a reduction in evapotranspiration and improvement in water delivery efficiency along the upper Pecos River in Texas were among the numerous desired effects. A paired study with treated and untreated riparian zones helped quantify the effects of saltcedar control on evapotranspiration and water delivery efficiency.

At the PREP study site near Mentone in West Texas (fig. 1) are two hydrologically similar and approximately equidistance riparian zones along a 1.5-kilometer $(\mathrm{km})$ reach of the Pecos River. The downstream riparian zone (fig. 2, site A) has been eradicated of all saltcedar. Imazapyr (2-[4-isopropyl-4-methyl-5-oxo-2 imidazoline-2-yl] nicotinic acid), an herbicide in the imidazolinone chemical family (Stell and others, 1995) was used to kill the saltcedar. The untreated upstream riparian zone (fig. 2, site B) is the control site.

\footnotetext{
${ }^{1}$ U.S. Geological Survey, West Texas Program Office, San Angelo, Texas.

2 Texas AgriLife Extension Service, Texas A\&M University, Fort Stockton, Texas.
} 


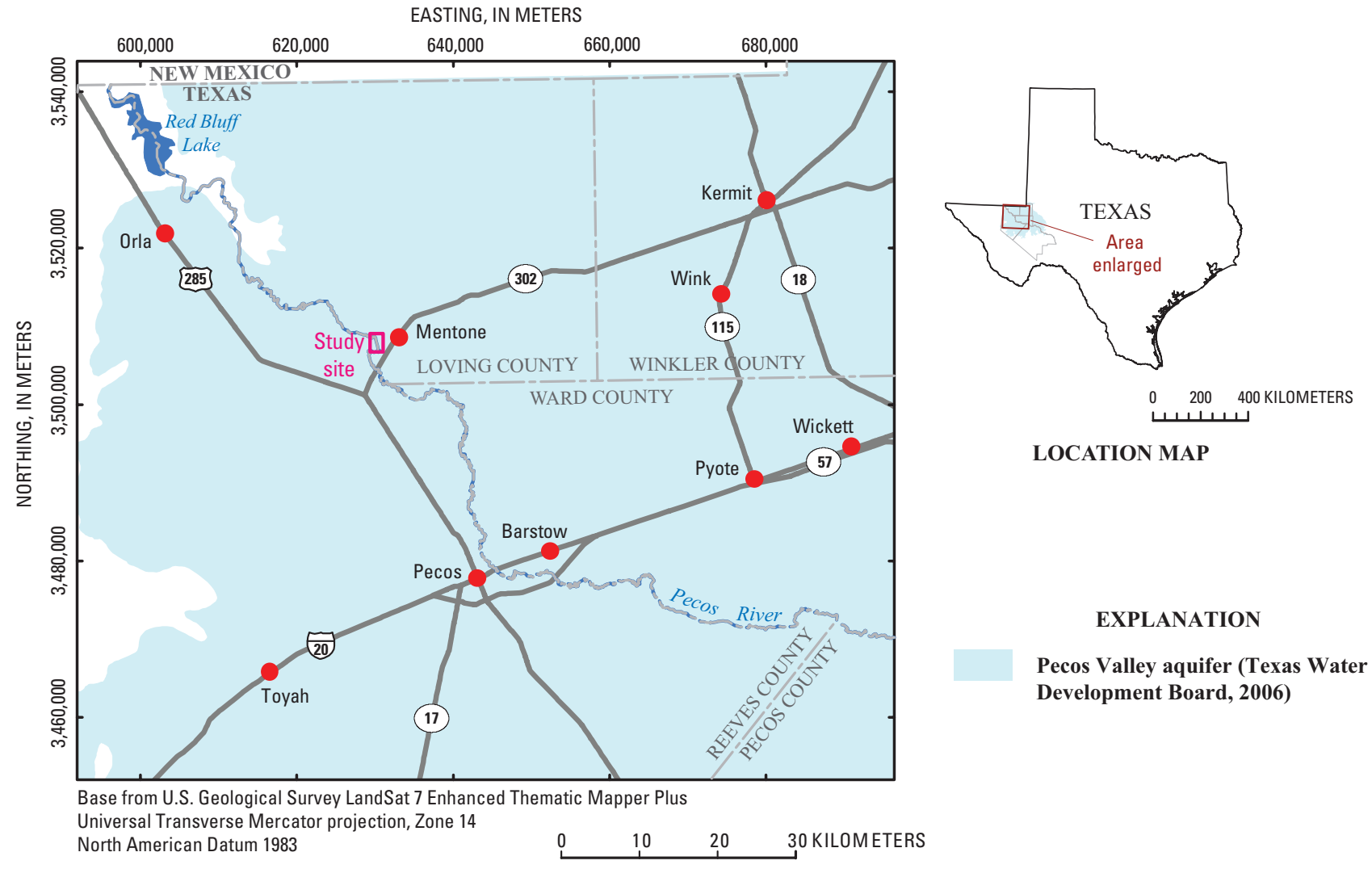

Figure 1. Location of Pecos River Ecosystem Project study site near Mentone,Texas.

Site A

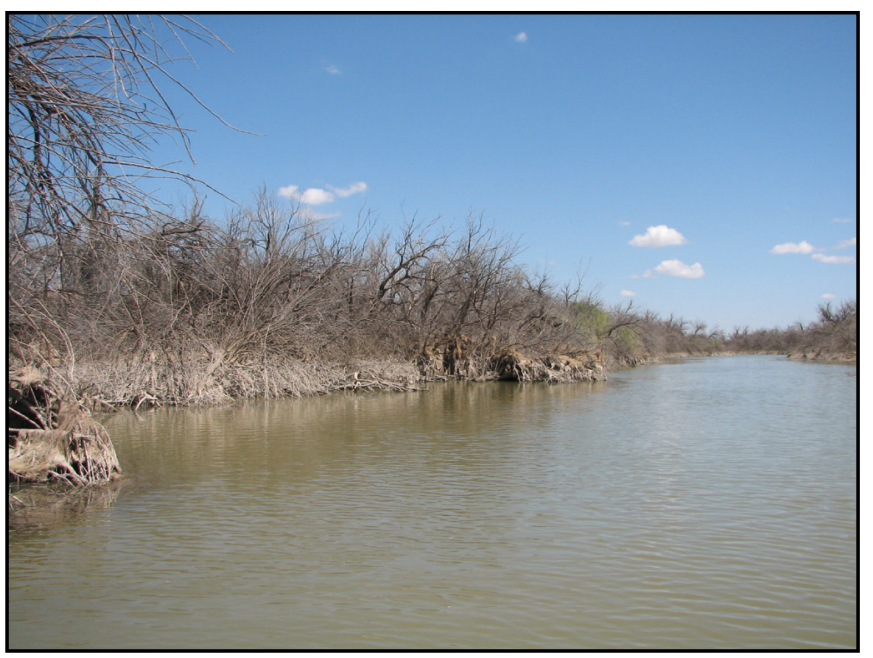

Site B

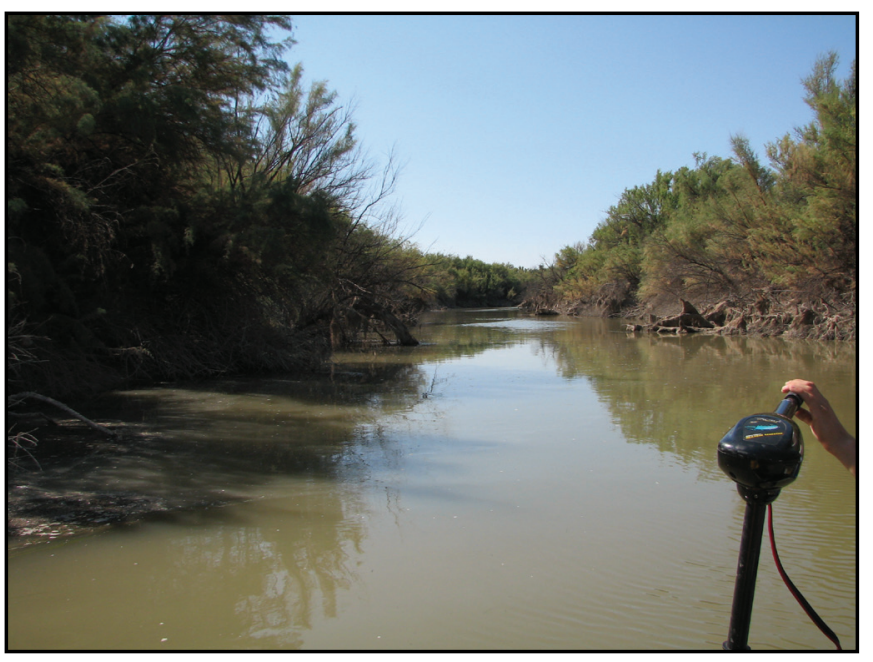

Figure 2. Treated reach (site A) and untreated (control) reach (site B) along the Pecos River, Pecos River Ecosystem Project study site near Mentone, Texas, 2006. 
As a part of the PREP, Texas A\&M University AgriLife is evaluating flows between the river and the surficial aquifer (Pecos Valley aquifer [formerly Cenozoic Pecos alluvium aquifer]) at the site, exploring the effects of saltcedar control on the fate of salvaged water and attempting to quantify water released to downstream flow and aquifer recharge (Texas A\&M AgriLife/Texas Water Resources Institute, 2009). Characterization of the aquifer beneath the treated and control zones (sites), which could contribute to a better understanding of the interaction between the river and the surficial aquifer in response to saltcedar control, is a necessary part of this effort. Accordingly, the U.S. Geological Survey, in cooperation with Texas A\&M University AgriLife, did a surface geophysical investigation at the PREP study site intended to determine shallow (to about 14 meters [m] deep) subsurface composition (lithology) in and near the treated and control sites during June-August 2006.

\section{Purpose and Scope}

This report presents the techniques and findings of directcurrent (DC) resistivity profiling at the PREP study site near Mentone, Tex., to determine the shallow subsurface composition of the Pecos Valley aquifer in and near a treated (to eradicate saltcedar) site and a control site on the Pecos River during June-August 2006. The report describes data acquisition and processing of land-based DC resistivity profiling applied in a 240-m section of the riverbank at the control site and waterborne DC continuous resistivity profiling (CRP) applied along a $2.279-\mathrm{km}$ reach adjacent to both sites. The resulting twodimensional sections of the shallow subsurface showing distributions of resistivity are then described. To translate variations in subsurface resistivity to variations in lithology, rock samples obtained from various depths (usually during well construction) at the site of interest are needed to match rock types to ranges of resistivity. Because sufficient rock samples were not available (wells installed in 1986 and 2003 were not drilled to depths below the riverbed), the specific lithology at the sites could not be determined from resistivity.

\section{Hydrogeology}

According to White (1971), the shallow subsurface in Ward County to the immediate southeast of the PREP site (and thus assumed representative of the PREP site) comprises clay, sand, gravel, and caliche in beds that differ widely in lithology and thickness over short distances. The rocks are unconsolidated or poorly cemented. Most of the relatively small annual rainfall (less than 254 millimeters [10 inches]) evaporates or is transpired by vegetation, thus recharge to the Pecos Valley aquifer is small. Groundwater occurs under water-table conditions adjacent to the Pecos River. Sheng and others (2007), as part of the PREP, reported that the Pecos River is hydraulically connected to shallow groundwater along the reach of the river adjacent to the treated and control sites; river stage generally is higher than adjacent groundwater levels.

\section{Direct-Current Resistivity Profiling}

Land-based DC resistivity profiling generally involves multiple electrodes put directly into the ground. The electrodes are configured in various geometries of current and potential pairs. Two current electrodes, used as a transmitter, are connected to an electrical current source to create a current field. An electrical potential field is created that is measured by a pair of potential electrodes used as a receiver. On the basis of the configuration of the electrodes (known as an array), the amount of current applied through the current electrodes, and the measured potential across the potential electrodes, apparent resistivity can be determined. Apparent resistivity depicts the resistivity of completely uniform (homogenous and isotropic) earth material (Keller and Frischknecht, 1966). A representation of the true subsurface resistivity is obtained through inverse modeling, the application of an iterative software program to compute the resistivity of an equivalent nonuniform earth material (described in the section "Inverse Modeling of Direct-Current Resistivity Data"). More complete descriptions of the DC resistivity method and typical resistivities of earth materials are in Grant and West (1965) and Zohdy and others (1974).

Waterborne CRP involves electrodes deployed in water so that electrical contact is maintained without the electrodes being driven directly into the ground (Ball and others, 2006). The floating array is pulled at a constant speed to collect continuous data (fig. 3). Multiple receiver channels on the resistivity meter allow for multiple potential electrode pairs to be used simultaneously with a single electrode pair serving as the current source (Ball and others, 2006). The waterborne CRP technique greatly reduces electrode installation time for large survey areas. More complete descriptions of waterborne CRP are in Ball and others (2006) and Masterson and others (2006).

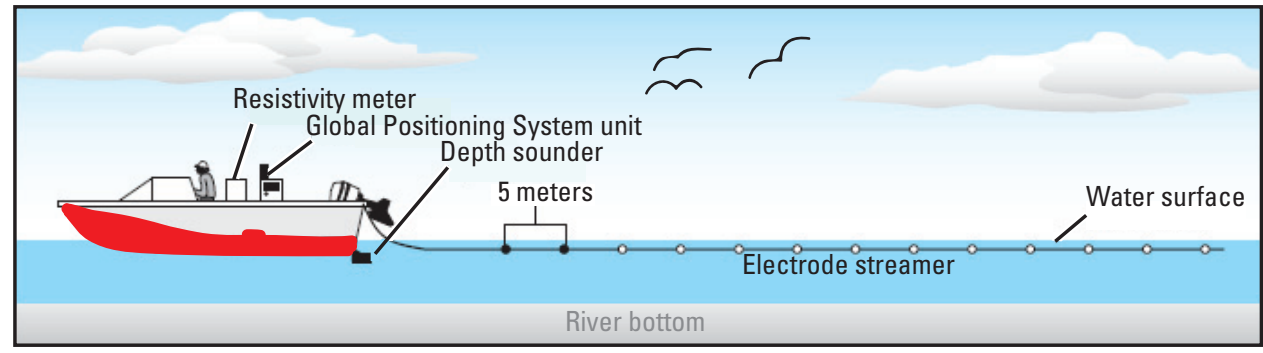

Figure 3. Diagram showing layout of waterborne direct-current continuous resistivity profiling system (modified from Ball and others, 2006). 


\section{A}

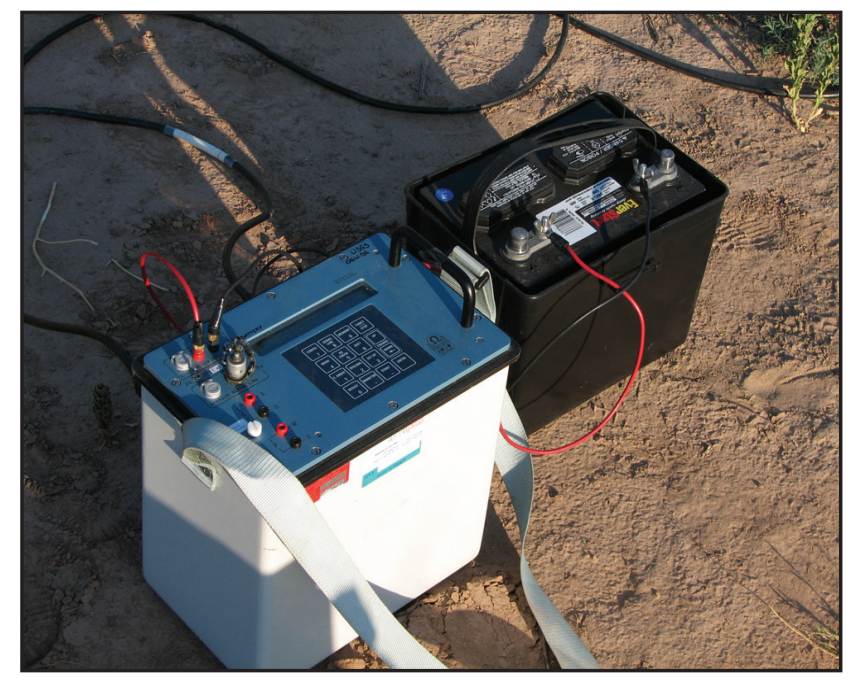

B

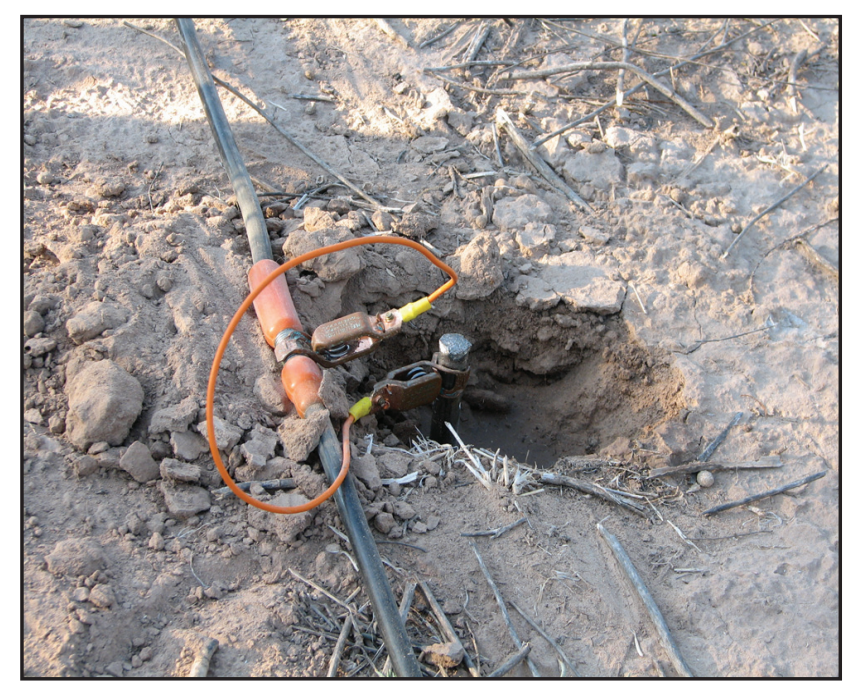

Figure 4. (A) IRIS Instruments Syscal Pro direct-current resistivity system and (B) stainless steel electrode connected to a direct-current resistivity cable near the Pecos River, Pecos River Ecosystem Project study site near Mentone, Texas, 2006.

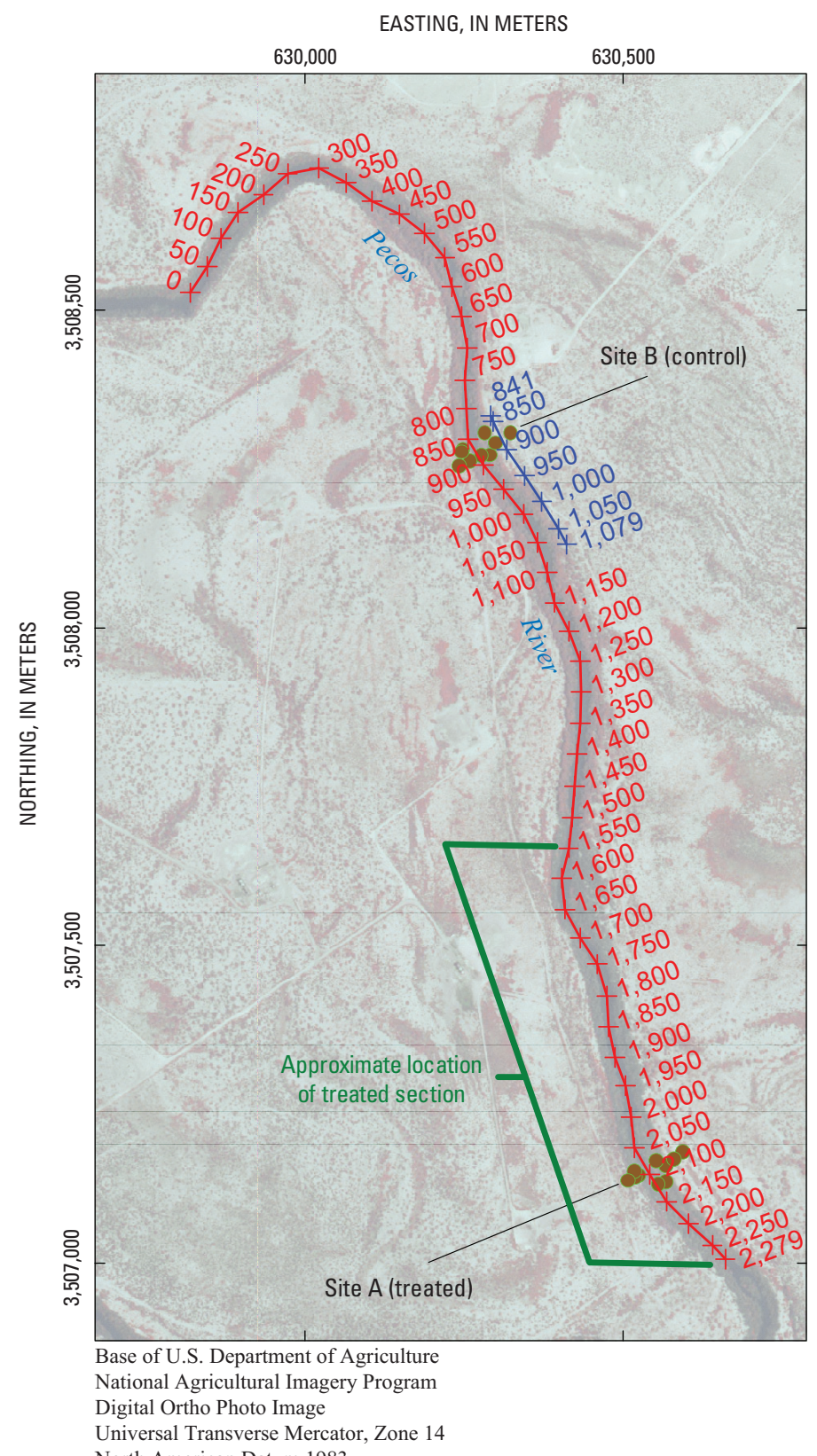

Universal Transverse Mercator, Zone 14

North American Datum 1983

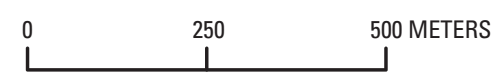

\section{EXPLANATION}

+ Surface direct-current resistivity profile with distance in meters

+ Waterborne continuous direct-current resistivity profile with distance in meters

- Well location

Figure 5. Land-based direct-current resistivity profile at site B (control) and waterborne continuous direct-current resistivity profile along the river adjacent to site $A$ (treated) and site $B$ (control), Pecos River Ecosystem Project study site near Mentone, Texas. 


\section{Data Collection}

All resistivity data were collected using the IRIS Instruments Syscal Pro system (IRIS Instruments, 2008) (fig. 4A). For the land-based survey, the system was deployed along a 240-m section of the bank to collect shallow subsurface resistivity data (fig. 5). The IRIS system incorporated 48 stainless steel electrodes (fig. 4B) spaced $2 \mathrm{~m}$ apart. The reciprocal Schlumberger array (fig. 6A) was applied to collect the land-based data. Because of dry conditions during surveys, saltwater was applied to each electrode to ensure good electrical contact with the ground. To obtain the $240-\mathrm{m}$ profile, the system was advanced along the profile line three times. Each time the system was advanced, $48 \mathrm{~m}$ of duplicate points were collected to ensure accuracy of the data and minimize data gaps in the deeper parts of the profile. Precise coordinates of each electrode were collected using a Trimble 5800 dual frequency kinematic Global Positioning System (GPS) unit (Trimble, 2008).

For the CRP surveys, a punt boat (fig. 7A) was used to tow a waterborne electrode streamer of 13 stainless steel electrodes with 5-m electrode spacing along the river reach adjacent to both sites (fig. 5). The streamer was built with a Kevlar support cord to attach the streamer to the boat. Pipe insulation (foam floats) were attached to the electrode streamer (between electrodes) to keep it at the surface of the river while keeping each electrode in the water (fig. 7B). The electrode streamer has $20 \mathrm{~m}$ of lead between the first electrode and the leading end of the streamer. Two oars and a trolling motor were used to maneuver the boat up and down the river.

A Garmin GPSMAP 188 Sounder (Garmin, 2008) was used to obtain geographic coordinates and water depth data near the back of the boat. These values were used to georeference the electrode locations and to define the approximate water depth below the electrodes. Sysmar version 04.08.01 (IRIS Instruments, 2008) software was used on a laptop computer to acquire the CRP data.

CRP data were collected three times along the $2.279-\mathrm{km}$ reach of the river, beginning about $850 \mathrm{~m}$ upstream from site $\mathrm{B}$ and continuing downstream past site A (fig. 5). The first dataset was collected using the reciprocal Schlumberger array (fig. 6A) while moving downstream. Throughout data collection, water-depth data from the depth sounder were compromised by the presence of moss and algae in the river. Because of this, the first dataset was not used for interpretation. For the two subsequent datasets, a polyvinyl chloride pipe marked at increments of $0.25 \mathrm{~m}$ was used to manually measure depth approximately every $20 \mathrm{~m}$ to verify the accuracy of the water depth data. The second dataset was collected using the dipoledipole array (fig. 6B) in the downstream direction. After data were collected in the final subsection, the boat was turned around and the software and system reconfigured to collect data using the reciprocal Schlumberger array. The boat was then navigated upstream until the electrode streamer snagged debris along the side of the river. Multiple upstream runs were necessary to collect the data; the flow of the river tended to
A

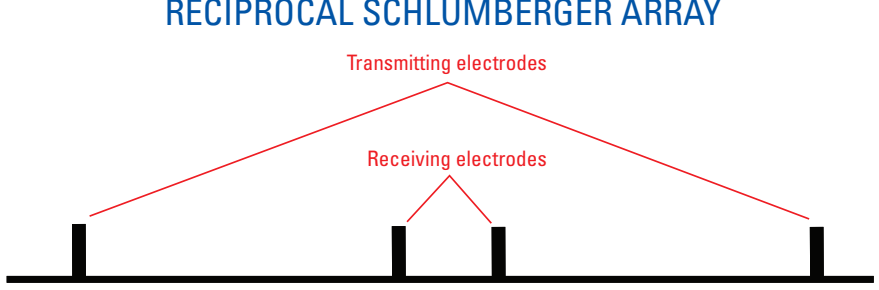

B DIPOLE-DIPOLE ARRAY

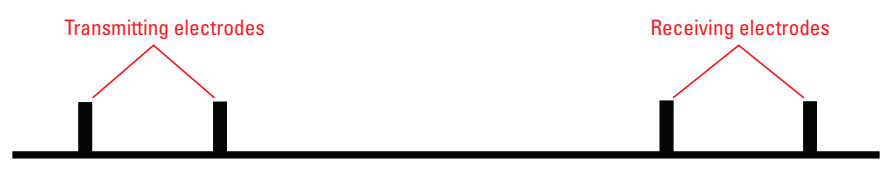

Figure 6. Diagrams showing $(A)$ reciprocal-Schlumberger and $(B)$ dipole-dipole arrays used at the Pecos River Ecosystem Project study site near Mentone, Texas, 2006.

have a greater influence on pushing the electrode streamer into the riverbank when towed upstream than when towed downstream. The final dataset was collected in the downstream direction using the reciprocal Schlumberger array.

\section{Inverse Modeling of Direct-Current Resistivity Data}

Apparent resistivity, as calculated from the field measurements, is the electrical resistivity of an equivalent electrically homogeneous and isotropic subsurface and is used to represent the average resistivity of the heterogeneous subsurface (Loke, 2004). To estimate the true subsurface resistivity, an inverse modeling program develops a model consisting of rectangular blocks of individual resistivities. The inversion program then determines the calculated system response of that model — the calculated apparent resistivities—on the basis of the field data. The root mean square (RMS) difference between the measured and calculated apparent resistivities is used to determine the accuracy of the model. The inversion program attempts to reduce the RMS difference by altering the simulated resistivity values and recalculating the apparent resistivities in a series of iterations until the RMS difference between the calculated and measured apparent resistivity no longer improves appreciably between iterations (more than 1 percent between iterations). The final model represents a nonunique estimate of the true distribution of subsurface resistivity. The inverse modeling process is described in detail by Loke (2004) and Yang (2006). 
Apparent resistivity data were inverted using EarthImager 2D version 2.1.6 Resistivity and Induced Polarization Inversion Software (Advanced Geosciences Inc., 2008). To obtain the best-fit model, EarthImager 2D was used to derive smooth model (Occam's) inversions (Constable and others, 1987; deGroot-Hedlin and Constable, 1990). Data were inverted using a maximum eight-iteration inversion, but each profile reached an acceptable RMS difference between iterations before the eighth iteration. Unprocessed apparent-resistivity data were initially filtered to remove poor-quality data points using the outlier analyses feature of the EarthImager 2D software. Data also were filtered during the inversion process on the basis of the resistivity inversion parameters. These include but are not limited to minimum resistivity (1 ohm-meter) and maximum resistivity (1,000 ohm-meters).

EarthImager 2D provides several graphical displays (scatter plot, convergence curve, and data-misfit histogram) to visualize the inversion results; these tools were used to evaluate the accuracy of the smooth-modeling results as well as the quality of the apparent-resistivity data. The data-misfit histogram allows the user to identify data points that are markedly different from the majority of the data. If there were data points that exceeded about 15 to 20 percent relative data misfit after the multiple iteration inversion, the points were removed and the section was re-inverted. The final inversion results were combined in Oasis montaj (version 6.4 [9m] HF1) (Geosoft Inc., 2008) to create

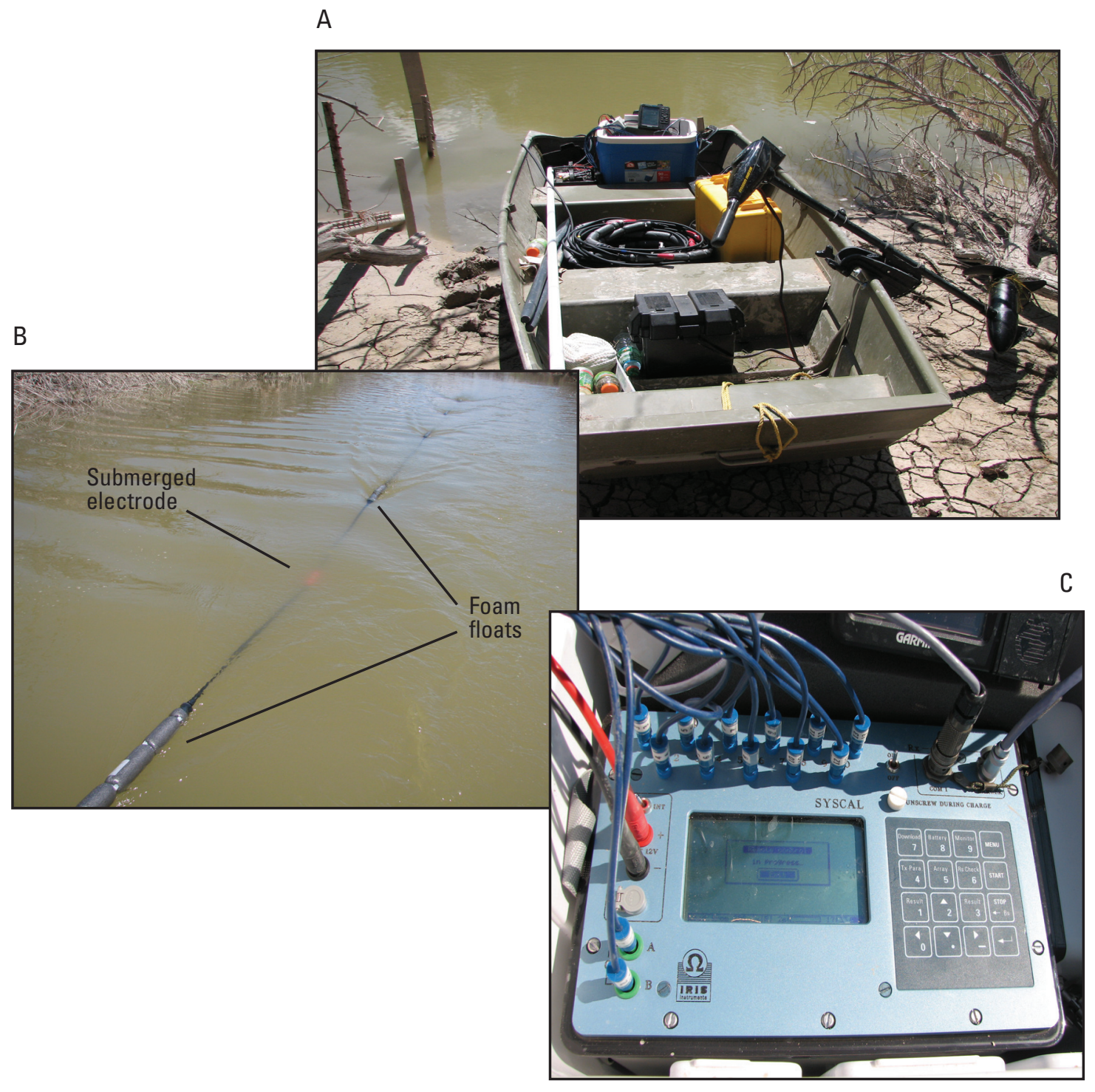

Figure 7. Waterborne direct-current resistivity equipment used at the Pecos River Ecosystem Project study site near Mentone, Texas, 2006: (A) punt boat with equipment and trolling motor, (B) waterborne electrode streamer with foam insulation for flotation, and (C) Iris Instruments Syscal Pro resistivity meter. 

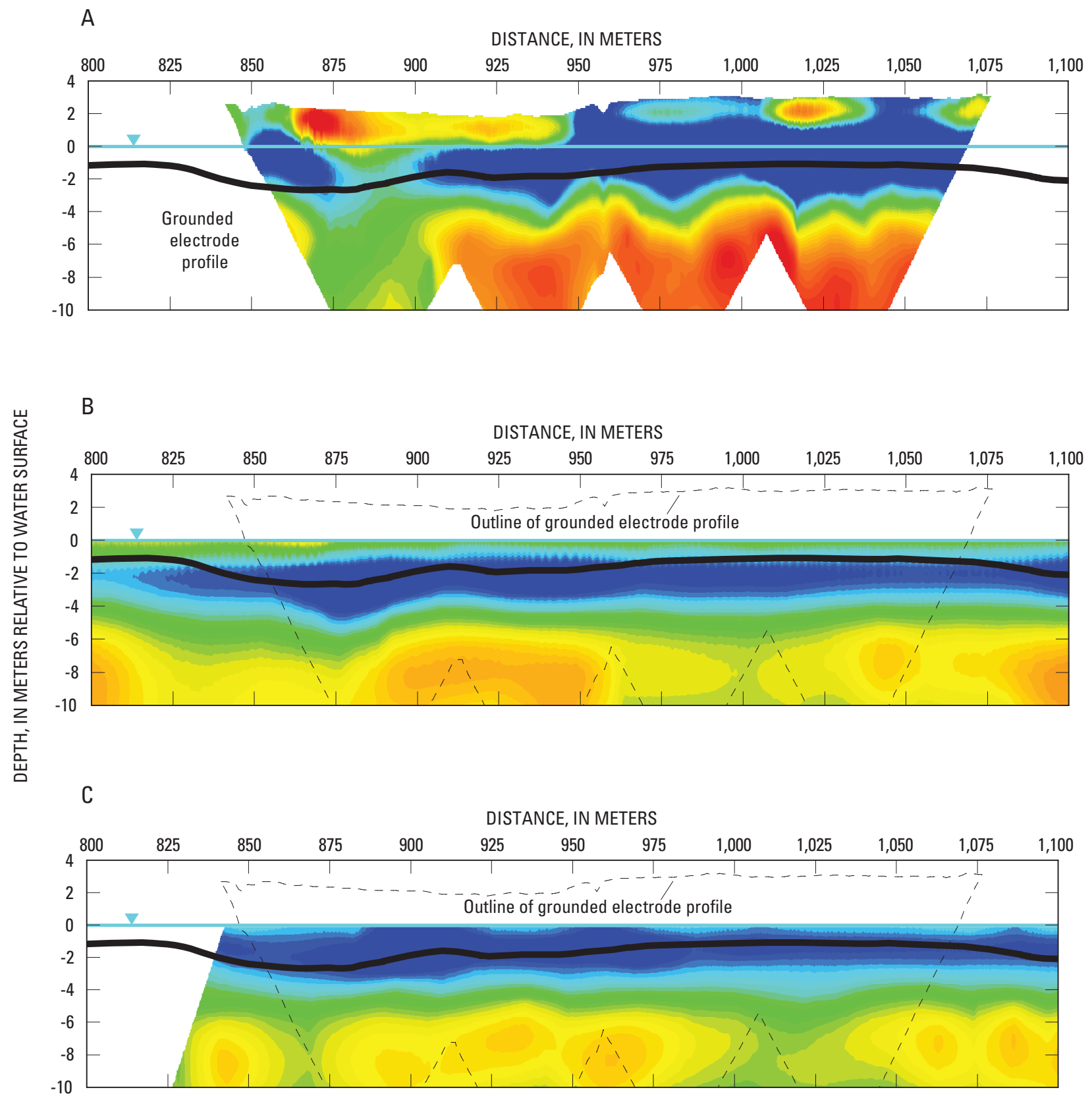

EXPLANATION

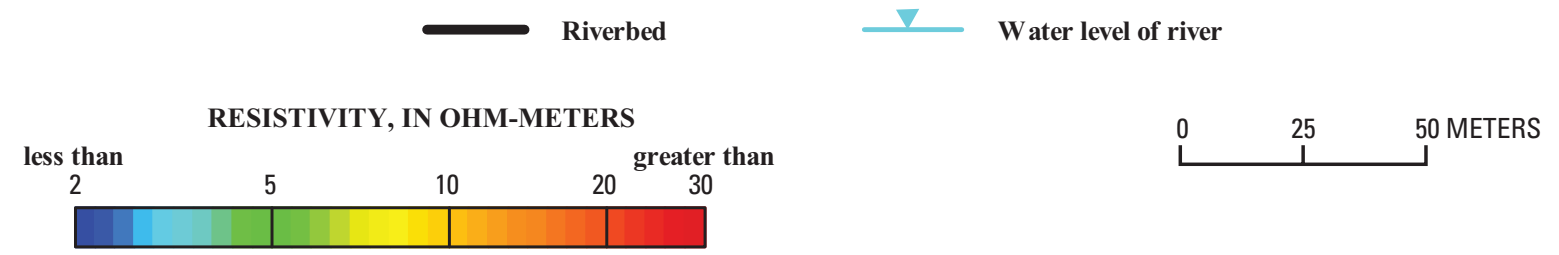

Figure 8. Smooth inverse model results of direct-current resistivity, Pecos River Ecosystem Project study site near Mentone, Texas, 2006: (A) resistivity section from reciprocal-Schlumberger land-based profile at the control site, (B) resistivity section from reciprocal-Schlumberger waterborne continuous profile from subreach of the river adjacent to the land-based profile, and (C) resistivity section from dipole-dipole waterborne continuous profile from subreach of the river adjacent to the land-based profile. 

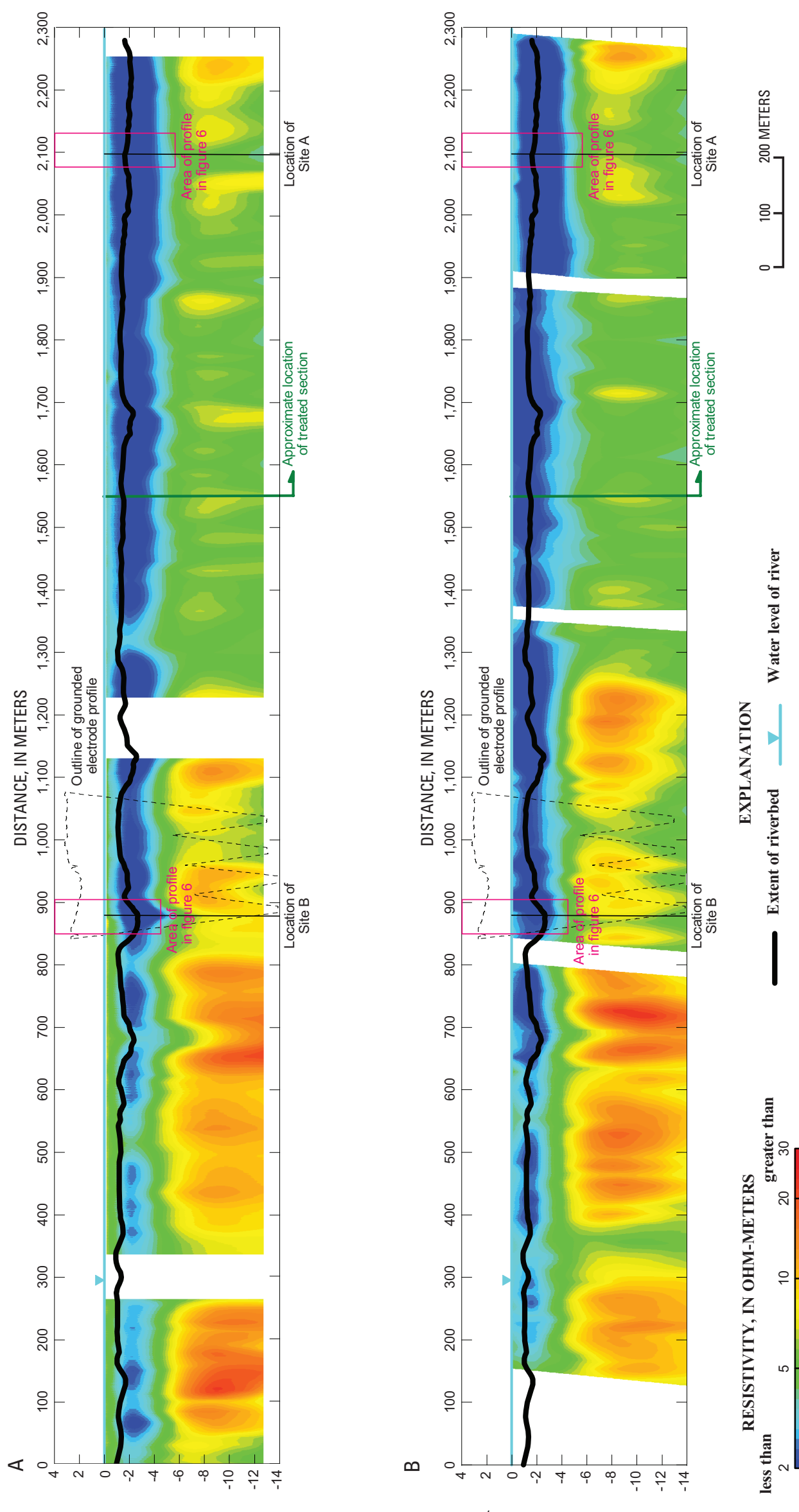

듬

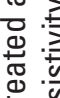

曹

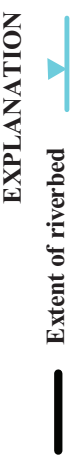

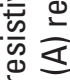

든

产 茪 늠 응

을 둥

.

ธั ฮั

농

은 흔

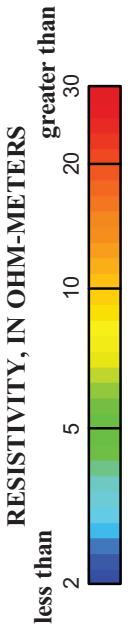
告先 is $\frac{\Phi}{0}$ 흔 बㄹ 틍

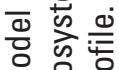
일 Ф 닌 Ф. 象 동웡 음 क or कs

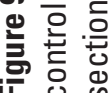


continuous two-dimensional resistivity sections of the reciprocal Schlumberger and dipole-dipole arrays.

\section{Distributions of Resistivity}

The smooth-model inversion results of each array collected produced generally similar resistivity structure; similar structure with RMS differences less than 1 percent engenders confidence in the results. The resistivity sections from the land-based DC survey and the CRP survey from the adjacent subreach of the river are shown in figure 8 .

The land-based survey showed that the subsurface generally is of relatively low resistivity down to about $4 \mathrm{~m}$ below the water surface, with the exception of a subsection immediately below land surface about $25 \mathrm{~m}$ long between distances 875 and $900 \mathrm{~m}$ (fig. 8A). Most of the section from about 4 to $10 \mathrm{~m}$ below the water surface is of relatively high resistivity. The reciprocal Schlumberger (fig. 8B) and dipoledipole (fig. 8C) configurations of the waterborne CRP surveys convey essentially the same electrical representation of the lithology (relatively low resistivity immediately below the riverbed but higher with depth) to $10 \mathrm{~m}$ below the water surface; but the CRP surveys show considerably lower resistivity than the land-based survey in the subsection from about 4 to $10 \mathrm{~m}$ below the water surface.

Figure 9 shows the results of the CRP surveys along the 2.279-km reach of the river adjacent to both the treated and control sites. The same relatively low resistivity zone from the riverbed to about $4 \mathrm{~m}$ below the water surface evident at the control site (fig. 8) appears over the entire length of the profile. Along the upstream approximately one-half of the profile, a slightly higher resistivity zone is observed from about 4 to $14 \mathrm{~m}$ below the water surface than along the downstream one-half. The downstream one-half of the profile shows the same zone but at a slightly lower resistivity.

The variations in resistivity could not be matched to variations in lithology because sufficient rock samples were not available; wells installed in 1986 and 2003 were not drilled to depths below the riverbed. Generally, relatively high resistivity zones correspond to more coarse-grained material or relatively fresh water, or both, and relatively low resistivity zones correspond to finer-grained silts and clays or more saline water, or both. To provide a definitive characterization of the shallow subsurface, additional data in the form of lithologic cores from new wells that would extend below the riverbed and water-quality samples from new wells screened at depths equivalent to those of the geophysical methods used in this study are needed.

\section{Summary}

At the Pecos River Ecosystem Project (PREP) study site near Mentone in West Texas are two hydrologically similar and approximately equidistance riparian zones along a $1.5-\mathrm{km}$ reach of the Pecos River. The downstream (treated) riparian zone has been eradicated of all saltcedar. The upstream (untreated) riparian zone is the control site. As a part of the PREP, Texas A\&M University AgriLife is evaluating flows between the river and the surficial aquifer at the PREP study site, exploring the effects of saltcedar control on the fate of salvaged water and attempting to quantify water released to downstream flow and aquifer recharge. Characterization of the aquifer beneath the treated and control zones (sites) is a necessary part of this effort. Accordingly, the U.S. Geological Survey, in cooperation with Texas A\&M University AgriLife, did a surface geophysical investigation at the PREP study site intended to determine shallow (to about 14 $m$ below the water [river] surface) subsurface composition (lithology) in and near the treated and control sites during June-August 2006.

Land-based direct-current (DC) resistivity profiling was applied in a 240-m section of the riverbank at the control site, and waterborne DC continuous resistivity profiling (CRP) was applied along a $2.279-\mathrm{km}$ reach of the river adjacent to both sites to collect shallow subsurface resistivity data. All resistivity data were collected using the IRIS Instruments Syscal Pro system. For the land-based survey, the system incorporated 48 stainless steel electrodes spaced $2 \mathrm{~m}$ apart. The reciprocal Schlumberger array was applied to collect the land-based data. For the three CRP surveys, a punt boat was used to tow a waterborne electrode streamer of 13 stainless steel electrodes with 5-m electrode spacing along the 2.279$\mathrm{km}$ reach. The reciprocal Schlumberger arrays (two surveys) and dipole-dipole array (one survey) were used to collect the CRP data.

Inverse modeling was used to obtain a nonunique estimate of the true subsurface resistivity from apparent resistivity calculated from the field measurements. The land-based survey showed that the subsurface at the control site generally is of relatively low resistivity down to about $4 \mathrm{~m}$ below the water surface. Most of the section from about 4 to $10 \mathrm{~m}$ below the water surface is of relatively high resistivity. The waterborne CRP surveys convey essentially the same electrical representation of the lithology at the control site (relatively low resistivity immediately below the riverbed but higher with depth) to $10 \mathrm{~m}$ below the water surface; but the CRP surveys show considerably lower resistivity than the land-based survey in the subsection from about 4 to $10 \mathrm{~m}$ below the water surface.

The CRP surveys along the $2.279-\mathrm{km}$ reach of the river adjacent to both the treated and control sites show the same relatively low resistivity zone from the riverbed to about 4 $\mathrm{m}$ below the water surface evident at the control site. Along the upstream approximately one-half of the profile, a slightly higher resistivity zone is observed from about 4 to $14 \mathrm{~m}$ below the water surface than along the downstream one-half. The downstream one-half of the profile shows the same zone but at a slightly lower resistivity. The variations in resistivity could not be matched to variations in lithology because sufficient rock samples were not available. 


\section{References}

Advanced Geosciences, Inc., 2008, AGI EarthImager 2D inversion and modeling software: accessed November 17, 2008, at http://www.agiusa.com/agi2dimg.shtml

Ball, L.B., Kress, W.H., Steele, G.V., Cannia, J.C., and Andersen, M.J., 2006, Determination of canal leakage potential using continuous resistivity profiling techniques, Interstate and Tri-State Canals, western Nebraska and eastern Wyoming, 2004: U.S. Geological Survey Scientific Investigations Report 2006-5032, 27 p.

Constable, S.C., Parker, R.L., and Constable, C.G., 1987, Occam's inversion-A practical algorithm for generating smooth models from electromagnetic sounding data: Geophysics, v. 52, no. 3, p. 289-300.

deGroot-Hedlin, C., and Constable, S.C., 1990, Occam's inversion to generate smooth, two-dimensional models from magnetotelluric data: Geophysics, v. 55, no. 12, p. 1,613-1,624.

DeLoach, J., 1997, Effects of biological control of saltcedar (Tamarix ramosissma) on endangered species: Temple, Tex., U.S. Department of Agriculture, Biological Assessment Report.

Garmin, 2008, GPSMAP 188/188C Sounder: accessed December 31, 2008, at https://buy.garmin.com/shop/ shop.do? $\mathrm{pID}=160$

Geosoft, Inc., 2008, Oasis Montaj version 6.4 (9m) HF1: accessed January 2, 2009, at http://geosoft.com/pinfo/ oasismontaj/index.asp

Grant, F.S., and West, G.F., 1965, Interpretation theory in applied geophysics-Part 3, Electrical conduction and electromagnetic induction methods: New York, McGraw-Hill, p. $384-572$.

Hart, C.R., White, L.D., McDonald, Alyson, and Sheng, Zhuping, 2005, Saltcedar control and water salvage on the Pecos River, Texas, 1999-2003: Journal of Environmental Management, v. 75, no. 4, p. 399-409.

IRIS Instruments, 2008, Principles of geophysical methods for groundwater investigations: accessed December 31, 2008, at http://www.iris-instruments.com

Keller, G.V., and Frischknecht, F.C., 1966, Electrical methods in geophysical prospecting: Oxford, United Kingdom, Pergamon Press, $519 \mathrm{p}$.

Kolb, T.E., 2001, Water use of tamarisk and native riparian trees, in Tamarisk Symposium, Grand Junction, Colorado, September 26-27, 2001, Proceedings: accessed January 2, 2009, at http://www.tamariskcoalition.org/ tamariskcoalition/pdf/tamarisk\%20ecology\%20and\%20 impacts.pdf
Loke, M.H., 2004, Tutorial-2-D and 3-D electrical imaging surveys: Geotomo Software, accessed November 1, 2006, at http://www.geoelectrical.com

Masterson, J.P., Sorenson, J.R., Stone, J.R., Moran, S.B., and Hougham, Andrea, 2006, Hydrogeology and simulated ground-water flow in the Salt Pond region of southern Rhode Island: U.S. Geological Survey Scientific Investigations Report 2006-5271, 56 p.

Sheng, Zhuping, McDonald, A.K., Hart, C., Hatler, W., and Villalobos, J., 2007, Quantity and fate of water salvage as a result of saltcedar control on the Pecos River in Texas: Texas A\&M University, Texas Agricultural Experiment Station/Texas Cooperative Extension, TR-304, $42 \mathrm{p}$.

Stell, S.M, Hopkins, E.H., Buell, G.R., and Hippe, D.J., 1995, Use and occurrence of pesticides in the ApalachicolaChattahoochee-Flint River Basin, Georgia, Alabama, and Florida, 1960-91: U. S. Geological Survey Open-File Report 95-739, 65 p.

Tamarisk Coalition, 2009, Tamarisk ecology and impacts: accessed February 9, 2009, at http://www.tamariskcoalition. org/tamariskcoalition/pdf/tamarisk\%20ecology\%20and\% 20impacts.pdf

Texas A\&M AgriLife/Texas Water Resources Institute, 2009, Pecos River Basin assessment program-Subtask 3.3 Quantity and fate of water salvaged as a result of saltcedar control: accessed January 30, 2009, at http://pecosbasin. tamu.edu/subtasks.php? view $=3.3$

Texas State Soil and Water Conservation Board and Texas Commission on Environmental Quality, 2006, 2006 Annual report-Managing nonpoint source pollution in Texas: accessed January 3, 2009, at http://www.tceq.state.tx.us/ assets/public/comm_exec/pubs/sfr/066_06.pdf

Texas Water Development Board, 2006, Major aquifers of Texas: accessed November 19, 2008, at http://www.twdb. state.tx.us/mapping/maps/pdf/aqu_maj_8xl1.pdf

Trimble, 2008, Trimble 5800 GPS receiver: accessed December 31, 2008, at http://www.trimble.com/5800.shtml

Weeks, E.P., Weaver, H.L., Campbell, G.S., and Tanner, B.D., 1987, Water use by saltcedar and by replacement vegetation in the Pecos River floodplain between Acme and Artesia, New Mexico: U. S. Geological Survey Professional Paper 491-G, 33 p .

White, D.E., 1971, Water resources of Ward County, Texas: Texas Water Development Board Report 125, 219 p.

Yang, Xianji, 2006, Instruction manual for EarthImager 2D version 2.1.0-Resistivity and IP inversion software: accessed November 1, 2006, at http://www.agiusa.com/files/ pub/softwareproducts.shtml 
Zohdy, A.A.R., Eaton, G.P., and Mabey, D.R., 1974, Application of surface geophysics to ground-water investigations: U.S. Geological Survey Techniques of Water-Resources Investigations, book 2, chap. D1, $116 \mathrm{p}$.

Publishing support provided by Lafayette Publishing Service Center

Information regarding water resources in Texas is available at http://tx.usgs.gov/ 
